\title{
Relationship between National Automotive Policy (NAP), innovation and automotive vendors' performance in Malaysia
}

\author{
Mohd Lutfi Iskandara ${ }^{a^{*}}$ and Aini Suzana Ariffin ${ }^{\mathrm{b}}$
}

${ }^{a}$ Lecturer, Faculty of Business Management and Professional Studies, Management and Science University (MSU), Shah Alam, Malaysia ${ }^{b}$ Senior Lecturer; Razak Faculty of Technology and Innovation; University Technology Malaysia (UTM), Kuala Lumpur; Malaysia

C H R O N I C L E

\section{Article history:}

Received: March 4, 2019

Received in revised format: April

92019

Accepted: April 24, 2019

Available online:

April 26, 2019

Keywords:

Government Support

Innovation

Vendor Performance

Structural Equation Modelling \section{A B S T R A C T}

Automotive industry in Malaysia started in 1985 with the launch of the first national car. However after thirty years, overall performance of the industry is still far behind the neighboring countries like Thailand and Indonesia which ranked first and second top producers in the automotive industry. In order for the automotive players in Malaysia to be globally competitive, innovation is an important element to drive competitiveness. Thus, the aim of this study is to determine the relationship between NAP strategies and innovation performance in the Malaysian automotive component industry. NAP was launched in 2006 with six main directions and strategies. Study is focused on local automotive vendor and a completed survey was completed with 300 respondents. Data was analyzed through structural equation modelling (SEM) using SmartPLS 3.0. Empirical evidence shows that NAP supports all types of innovation among automotive vendors in Malaysia. The study also found innovation mediates between National Automotive Policy (NAP) and vendor's performance except in the process innovation. This supported previous research in this area where government policy partially mediates on firm competitiveness. The finding of the study suggests NAP is still relevant for the automotive vendors in Malaysia in improving innovation and performance.

(C) 2019 by the authors; licensee Growing Science, Canada

\section{Introduction}

During the past thirty years the automotive industry in Malaysia has faced many up and down situations. The inception of Malaysia's first national car in 1985 demonstrated an achievement of agricultural country transforming to industrial country. Slightly after ten years the national industry launched the national company Proton dominated $80 \%$ of the passenger car sales in Malaysia. However the performance of the national company deteriorated when the WTO (World Trade Organization) policy was introduced in 1995 where local firms were no longer allowed to enjoy protection policy of its national industry (Natsuda \& Thoburn, 2014). In 2003, the WTO launched AFTA (ASEAN Free Trade Area Agreement) in 2003 with the initial idea to promote economy activities among ASEAN members. Following the launched of AFTA, tax and import duties were reduced between ASEAN countries allowing lower car prices among ASEAN countries. This resulted low production cost countries like Indonesia and Thailand to take advantage from this situation. Furthermore, both countries had no national automotive companies 
like Malaysia and dominated by Japanese giant automotive companies which gave the benefit of economic of scale production and resulted in lower car prices (Sakura et al. 2013). As a result, the sales of Proton cars slummed into half of what it used to sell in mid 1990s and affected the performance of the automotive vendors as well. In improving the performance of Malaysian automotive industry, NAP (National Automotive Policy) was initiated in 2006 with the aim to improve the overall competitiveness of automotive industry in Malaysia.

\subsection{Research Issue}

Automotive industry has been regarded as the industry of the industries since it provides opportunities for SMEs to be involved in this sector as well as work opportunities. The automotive industry in Malaysia comprise of two national automotive companies in Malaysia, eleven automotive assemblers and eight hundreds vendors which has strengthen the automotive ecosystem and has created 350,000 job opportunities in Malaysia (MIDA 2012). Thus, every government sees this industry needs to be protected from the presence of foreign automotive producer. In fact automotive protectionist policy has been practiced by many developed countries like United Kingdom, Germany and France to protect their automotive industries in the 1950s (Chang 2007). Other countries like South Africa also had its own automotive policy which is the Motor Industry Development Program (MIDP) started in 1961 to protect its local automotive industry. Ranawat and Tiwari (2009) reported India successful giant automotive companies like Tata Motors and Bajaj Auto today were the results from indigenisation and protection policies implemented in the country. On the whole, automotive policies has proven to be succeeded in developing many automotive industry countries (Barnes et al. 2004; Ao \& Gelman, 2012).

Malaysia started the first automotive policy in 1967 with the Import Substitution Policy (ISI). During this time, government objective was only to reduce the imported automotive components parts from abroad. The national policy then progressed to various policies to help the automotive components and parts manufacturers. For example the government has introduced rules and policies to help local vendors, for example the localization policies, mandatory deleted items (MDI) and local material content policy (LMCP). These policies proved to be effective at the initial stage in the 1990s and has increased the local contents in the production of local automobiles and increased the participation of Bumiputera vendor in the industry. Thus, under the Third Industrial Master Plan (IMP3) 2006-2020, the Malaysian government launched NAP with six objectives

i. to promote a competitive and sustainable domestic automotive industry especially the national car manufacturers;

ii. to develop Malaysia as a regional automotive hub in specific are;

iii. to increase value-added activities in a sustainably while developing domestic capabilities;

iv. to increase exports of vehicles and automotive components;

v. to promote Bumiputera participation in the total value chain of the domestic automotive industry; and

vi. to safeguard consumer interests by offering safer and better quality products at competitive prices.

However, despite the right objectives of the automotive policy to promote competitiveness, the performance of the automotive vendors in Malaysia are still low and not globally competitive. Current literature shows that Malaysian automotive vendors are still not able to become globally competitive vendor (WanPing et al., 2013). This has resulted the automotive vendors unable to produce fragmented parts produced. This has caused automotive parts unable to be capable of producing large quantities and can enjoy the benefit of high economic of scales production.

Referring to Fig. 1, although there is incremental value in sales of automotive components parts in Malaysia from year to year, the value of imports figure still lower than the export figures which denoted trade deficit in Malaysian automotive components industry. 


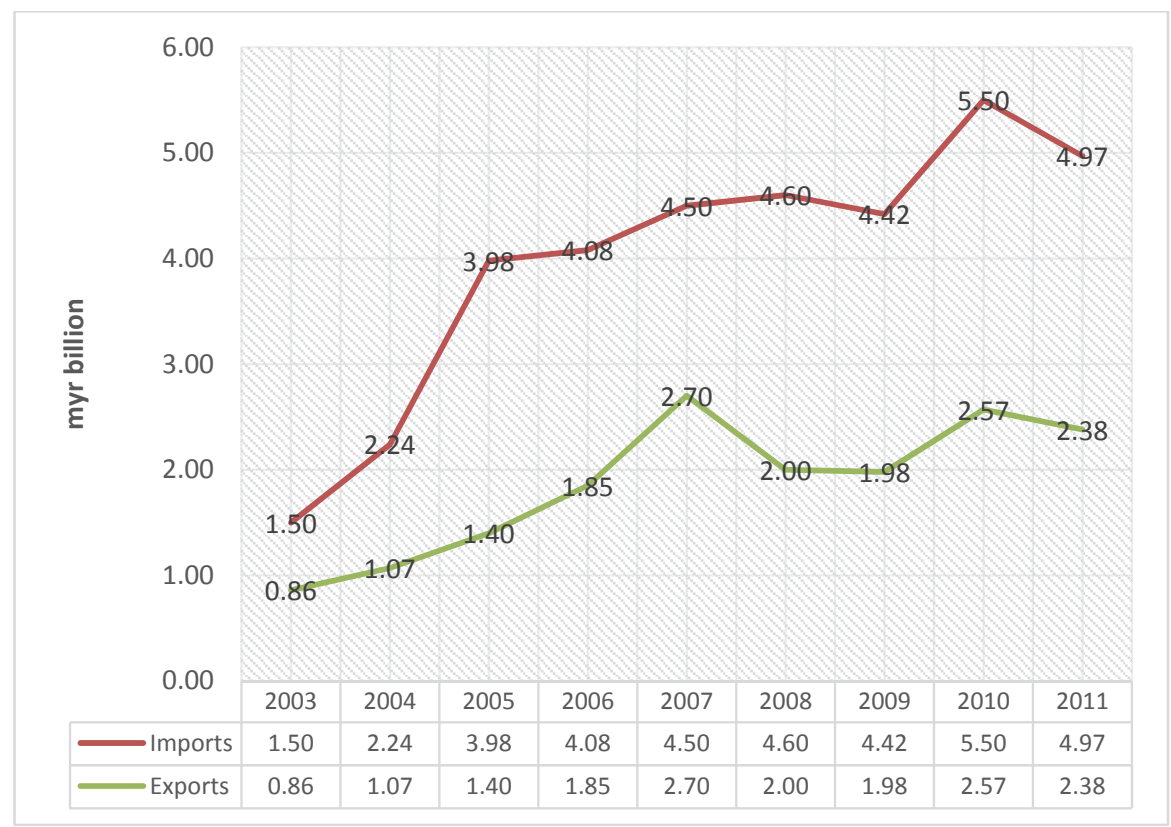

Fig. 1. Import and export values of Malaysia automotive components.

(Source: ASEAN Secretariat 2014)

Malaysia automotive parts are also reported to cater for domestic market only and are unable to compete with these global suppliers. This has hindered the local vendors and to compete with the international OEMs (Sakura et al., 2012). Segawa et al. (2014) mentioned the competitiveness of local vendors was relatively low because they were protected by the government.

\section{Literature review}

\subsection{Major strategies in National Automotive Policy (NAP)}

In order to meet the objective, the government has outlined six strategies to the objective in the Industrial Master Plan. Each strategy entails further incentives to influence the competitiveness of the automotive vendors in Malaysia which are explained as follows;

Investment Strategy - Issuance of new Manufacturing License for motor vehicles in the category of EEV and exemption of import tax and excise duty for an assembly of Completely Knocked Down (CKD) hybrid and electric vehicles are some of the efforts to empower car industry. Basically this strategy is stimulate the foreign direct investment in Malaysia. Current trend of automotive production is towards green vehicles and thus the government is encouraging and allowing foreign automotive manufacturer to produce this type of vehicles in Malaysia. Furthermore there are no electric vehicle (EV) production in Malaysia currently being produce commercially.

Technology and Engineering Strategy - Provision of soft loan to develop EV infrastructure such as PlugIn-Hybrid-Vehicle charging station and pre commercialization activities. The provision of the loans to automotive vendors is to produce the facilities for charging station in order to promote the use of EV in Malaysia.

Market Expansion Strategy - Establishment of Distribution Infrastructure Network (DIN) and Automotive Parts \& Components For Market Expansion (APCIMEX) to drive export sales. This is a non-financial incentive used by the government to enhance the competitiveness of the vendors through networking. 
The automotive vendors in Malaysia were reported to be fragmented and only competing in the local market.

Human Capital Development Strategy - Human capital development programs such as MAJAICO and Malaysia Automotive Institute (MAI) may contribute to this industry. This is also a non-financial incentives used by the government to give expertise to the local vendors. Program so far managed to provide expertise from Japan to the local vendors.

Supply Chain Development Strategy - Provision of soft loans to develop new tooling for Tool, Dies and Mould manufacturers. The soft loan provided amounted to RM 100 million per year for the vendors to purchase and install high technology machine.

Safety, Security and Environment Strategy - Introduction of voluntary vehicle inspection program (VVIP) to ensure roadworthiness of vehicle. Adoption of global 3R (Reduce, Reuse, Recycle) standard as Malaysian Standards in the automotive components. These programs were designed to enhance safety and road worthiness for the road users in Malaysia indirectly would promote the automotive industry.

From the strategies outlined in the NAP, it can be generalized that the government strategies in NAP can be further sub-categorized into two categories which are the financial incentives and non-financial incentives. Financial incentives include loans and subsidies and the non - financial incentives such as issuance of manufacturing license, human capital development program and other programs related. Policy makers prefer to mix the use of financial and non-financial incentives to promote the growth of industry. In NAP strategies, both types of incentives were used by the policy maker.

\subsection{The effect of government policy on innovation}

The importance of government policy to firm's innovation has been conducted in many previous studies. Rousseau et al. (2016) mentioned in their study there might be moderation effect such as national culture on the innovation performance relationship. There is a synergetic relationship between government policy and practice of innovation. According to Panayides and Venus Lun (2009) innovation is defined as the adoption of an idea or behavior, a system, process or policy to the organization. Zhang et al. (2019) in their study mentioned institutional support can be defined as government support to firms in order to reduce the adverse effects of the inadequate institutional government infrastructure. The institutional support obtained from government consists of tangible and intangible resources such as beneficial policies and programs. One of the aim in government policy is to strengthen the interactions between actors in the system. Government policy is important factor in improving innovation and enhancing competitiveness. This is because one of the factors to improve product innovation requires company to invest in Research \& Development (R\&D). However expenditure on R\&D is relatively expensive and not many organizations have the capability to invest especially in high technology industry like automotive. Furthermore, most private companies are looking for quick and safe returns from their investments (Guan \& Yam, 2015). Thus, the role of government in financing the R\&D is deemed necessary. Through the NAP, the government provides loans for the vendors to invest in new techniques of production and hence giving potential for the vendors to perform. The effect of government policy on innovation can also be discussed from the evolutionary economics models which introduced the concept of National Innovation System (NIS). NIS comprises of firms and government institutions economic agents (Freeman 1995; Chidoko \& Mashavira, 2014; Yuliansyah, 2015; Abiodun, 2014; Sabri \& Sweis, 2015; Elkhayat \& ElBannan, 2018; Syadullah, 2018; Hallunovi \& Berdo, 2018 ; Obodo, 2018). NIS is the synergy of economic development model which emphasized government role in developing economy. Porter (1990) further mentioned in his theory of competitiveness of nations that government as an essential helper or supporter of industry employ a host of policies to contribute directly to the competitive performance of strategic or target industries. 


\subsection{The effect of innovation on vendor's performance}

There are many ways performance can be measured. First, the effect of innovation can be measured by innovative performance since it is the combination of overall organizational achievements and as a result of continuous renewal and improvement efforts. Jugend et al. (2018) defined innovative performance with focuses on both the technical aspects of innovation and the introduction of new products in the market. Innovation literature claims that innovation is one of the key factors for firm to succeed and to gain competitive advantage (Porter 1990; Singh \& Jayraman, 2013; Khan \& Ali, 2017; Diemer et al., 2018). Innovation study has become important in developing industries. OECD (Organization for Economic Co-Operation and Development) countries defined innovation as the implementation of a new or significantly improved product (good or service), or process, a new marketing method, or a new organizational method in business practices, workplace organization or external relations (OECD 2005). The Oslo Manual, produced by the OECD set a benchmark for innovation surveys and research for its members. There are four main types of innovations as defined in the OSLO Manual which are as follow:

i. Product innovation: A product innovation is a new or significantly improved product modification with respect to its characteristics or intended uses. This includes significant improvements in technical specifications, components and materials.

ii. Process innovation: A process innovation is production or delivery method. This includes significant changes in techniques, equipment and/or software (e.g. installation of new or improved manufacturing technology, such as automation equipment or real-time sensors that can adjust processes, computeraided product development).

iii. Marketing innovation: A marketing innovation is the implementation of a new marketing method involving significant changes in product design or packaging, product placement, product promotion or pricing. Marketing innovations are aimed at better addressing customer needs, opening up new markets in order to increase revenue.

iv. Organizational innovation: An organizational innovation is the implementation of a new organization business practices, firm organization or external relations. Organizational innovations will improve workplace satisfaction and at the end will increase work efficiency at the organization.

\subsection{Development of hypothesis and research framework}

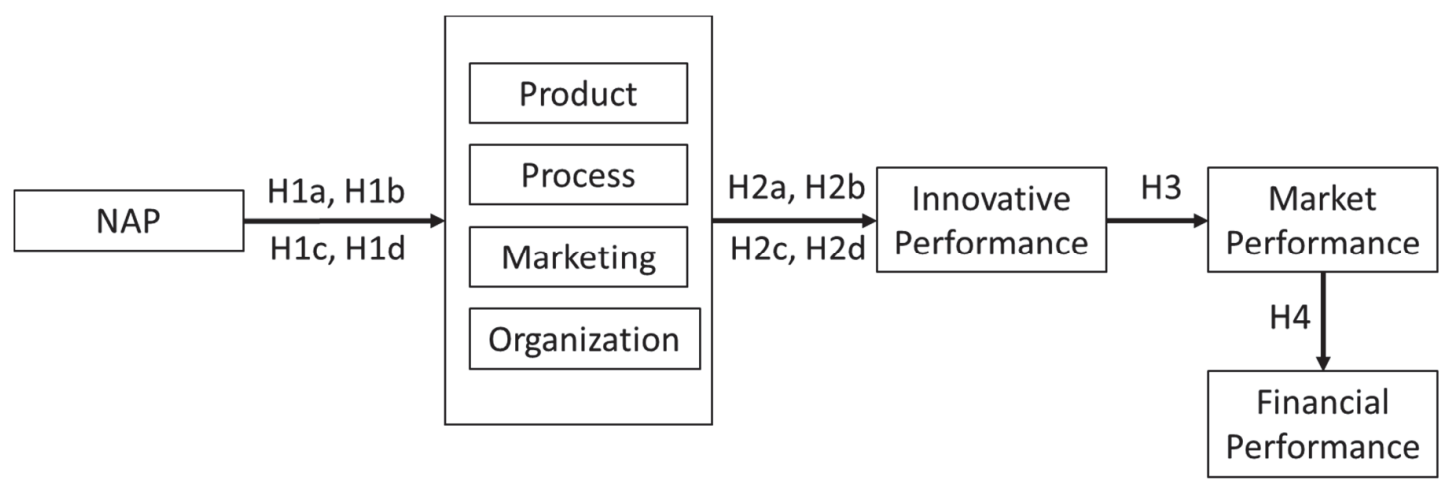

Fig. 2. Research framework and hypothesis

There are many forms of government supports designed to help organization. Jugend et al. (2018) in their study mentioned government supports are categorized into grants, tax incentives, state-sponsored labs or direct investment through public venture capital. Innovation research suggests that government support 
in the form of public policy instruments is closely associated with private R\&D spending and innovation. Wei and Liu (2015) studied the effect of Chinese government support to its manufacturing firm and founf important findings in this field of research because China succeeded transforming its country. The government support can be categorized into vertical support and horizontal support. Vertical support are in the form of direct research and development (R\&D) subsidies. Government R\&D subsidies such as government scientific research project is more toward selective strategy where government allocate subsidies for specific industry. Horizontal support is a regional innovation policy positively influences the innovation performance of overall Chinese firms. Horizontal support are given to across manufacturing industries or in other word it is also known distributive strategy compared with vertical support which is in selective strategy. In another view, government support is sub-categorized into two types which are financial incentives and non-financial incentives. Guan and Yam (2015) studied the effect of government support to manufacturing firms in China during its economic transition period in the mid-1990s. The study described the financial incentives into three types which are direct earmarks, government loans and tax credit incentives. From the study it was found out that government loans and tax credits were found to be positively influenced the firm innovative performance. However direct earmarks was found not significant in improving the firm's performance. Based on the above studies, NAP can be regarded as the usage of mix of strategies, both the financial incentives and non-financial incentives. Mix usage of both strategies are preferred to use by policy maker since it gives more effective results in developing economy (Wei and Liu 2015; Kadasala et al., 2016; Forgha et al., 2018).

According to Zhang et al. (2019) there are mixed findings on government influence on product and process innovation. Government support to process innovation is vital in improving vendor's innovation. According to Gunday et al. (2011) process innovation is defined as the implementation of a new or significantly improved production or delivery method such as changes in techniques, equipment or software is defined as process innovation. Govindaraju et al. (2013) studied the different effects of government support to product innovation and process innovation and found out government incentives to be more significant in process innovation. In NAP, the human capital development strategy and supply chain management are expected to give positive influence in improving process innovation and vendor's performance. Based on these literatures, the following hypotheses are proposed:

H1a - NAP has a positive relationship with product innovation in improving vendor's performance. $\mathrm{H} 1 \mathrm{~b}$ - NAP has a positive relationship with process innovation in improving vendor's performance. H1c - NAP has a positive relationship with market innovation in improving vendor's performance. H1d - NAP has a positive relationship with organization innovation in improving vendor's performance.

There is a growing body of evidence suggesting that alliances between innovation and performance are increasingly important to firm's competitiveness and performance (Rousseau et al., 2016). Large numbers of innovation performance studies conclude higher innovativeness are associated with higher performance. The positive effect of innovation to performance were found positive on the Community Innovation Survey in Sweden which distinguished sixteen innovation strategies and included Schumpeterian four types of innovations strategies (Karlsson \& Sam, 2015). Hence, the basic four types of innovations strategies are used in the study. However majority of researches tend to focus only on single type of innovation or the most two types of innovation which are process and product innovations. There are also studies on green innovation adoption and its effect on firm performance which has sparked interest among Malaysian researchers (Zailani et al., 2015; Habidin et al., 2016; Nze, Ogwude et al., 2016; Hang et al., 2016; Owusu-Antwi et al., 2017; Ahmed et al., 2018).

Innovation has been proved to give significant improvement to automotive industry and automotive components and parts industry. Atalay et al. (2013) and Gunday et al. (2011) studied the effects of product, process, organization and marketing innovations on Turkish automotive supplier industry. Their findings revealed product and process innovations had positive effects on firm performance in this industry. Firms 
should put emphasis on product and process innovation because automotive industry is in high technology sector and among the most competitive sectors in the world economy. More recent studies adapted the same approach and resulted the same outcome. Product, process, marketing and organization innovation have positive effects to firm performance (Karabulut, 2015; Rajapathirana \& Hui, 2018). From these literatures, it is understood that four types of innovations strategies are important in influencing vendor performance. Thus, the following hypotheses are proposed:

$\mathrm{H} 2 \mathrm{a}$ - Product innovation has a positive relationship with innovative performance.

$\mathrm{H} 2 \mathrm{~b}$ - Process innovation has a positive relationship with innovative performance.

$\mathrm{H} 2 \mathrm{c}$ - Market innovation has a positive relationship with innovative performance.

$\mathrm{H} 2 \mathrm{~d}$ - Organization innovation has a positive relationship with innovative performance.

Innovative performance can be measured with the following indicators which are number of R\&D inputs, patent counts and patent citations (Hagedoorn \& Cloodt 2003). The result from the new product development is understood to offer opportunities for companies to increase sale and expand the market share. Hence, the ultimate result from innovative performance should reflect in the market performance and financial performance. Many studies have used innovative performance as mediator to market and financial performance (Gunday et al., 2011 Atalay et al., 2013; Karabulut, 2015; Rajapathirana \& Hui, 2018).

There are limited researches which explained the relationship between the innovation performance and market performance. However studies by Rajapathirana and Hui (2018) defined market performance as the ability of firms to gain market related outcomes than their rivals with respect to customer satisfaction, new customer acquisition and loyalty in the context of service industry (Ahmed et al., 2016; Ali \& Haseeb, 2019; Haseeb et al., 2018; Haseeb., 2019; Suryanto et al., 2018). Gunday et al. (2011) measured market performance in Turkish automotive vendor competitiveness study with total sales, penetration of market and customer satisfaction. Based on these literatures the following hypothesis are proposed:

H3 - Innovative performance has a positive relationship with market performance.

H4 - Market performance has a positive relationship with financial performance.

From the above literatures, the proposed relationships between NAP, innovation and vendor's performance are discussed and the respective variables are developed. The research framework developed in this study is illustrated as in Fig. 2. The framework briefly describes government support through NAP influence to vendors' innovation and ultimately enhance performance.

\section{Methodology}

In order to understand the effect of NAP towards innovation and performance, a survey questionnaire was constructed which consists of three important sections. Section A consists of six strategies from the NAP which are the investment strategy, technology strategy, market expansion strategy, human capital strategy, supply chain strategy and lastly safety, security and environment strategy (MITI 2014). Six questions were asked to the vendor whether the strategies in the NAP is important to their organization on five-points Likert scale ranging from 1='strongly disagree', 2='disagree', 3='neutral', 4='agree' and $5=$ 'strongly agree'. The questions are listed in the appendix. To develop the questionnaire, the researcher first defined the construct by searching the literature and seeking expert opinions. A panel of content experts is then asked to review the potential scale items and validate that they are appropriate indicators of the construct (Devon et al., 2007). The first two main constructs in this study which are innovation and performance were adapted from multiple studies in innovation types on firm performance (Gunday et al. 2011; Atalay et al., 2013; Kalay \& Lynn, 2016; Alam 2013; Rajapathirana \& Hui, 2018). Since all these studies measure the relationship between innovation and firm performance, the researches adapted 
and adopted the questions used. For vendor's performance, three constructs were asked to the respondents which are the innovative performance, market performance and financial performance. The innovative performance constructs consist of four indicators, market performance consists of four indicators and financial performance consists of three indicators. All the performance indicators, respondents were asked to indicate the performance of the organization based on five points Likert scale ranging from 1='very unsuccessful', 2='unsuccessful', 3='neutral', 4='successful' and 5='very successful'.

Innovation was divided to 4 indicators which are product innovation, process innovation, organization innovation and marketing innovation. 14 questions on innovation were asked. For innovation, respondents were asked to indicate on the innovation practice on five points Likert scale ranging from $1=$ 'not implemented', 2 = 'imitated from national market', 3 = 'imitated from international', 4 = 'current products were improved', 5 = 'original product/process/marketing/organization innovation were implemented'. The innovation indicators were used in the study by Atalay et al. (2013) which explored the relationship between innovation and firm performance from Turkish automotive supplier industry. Since most of the questions adapted were from automotive, textile, chemical, metal products, machinery, electrical home tools and equipment industries from other countries, the researchers performed expert validity test in the context of Malaysia automotive industry.

The questionnaire was distributed to 300 vendors registered in Malaysian Automotive Component Parts Association (MACPMA) and Proton Vendors Association (PVA) for the period of six months from December 2017 to May 2018. Simple random sampling was adopted since all the vendors registered under the MACPMA and PVA were approached. Simple random sampling was considered to be the feasible method since sampling frame for the target population are only vendors that supplying parts to Proton. All of these companies had an equal chance in participating in this research. Furthermore, it was more economical compared to other methods as the subjects of the sample were selected from the entire population (Bell et al., 2013). The sample size is considered to be adequate and valid for the study because it has fulfilled the formulas in determination of sample size and represented the actual population of 800 vendors in Malaysia. Tabachnick and Fidell (2013) gave a simple formula for calculating sample size requirements. By taking the number of independent variables that were used in the study: $\mathrm{N}>50+8 \mathrm{~m}$ (where $\mathrm{m}=$ number of independent variables). In this study, four independent variables were used and thus the calculation was as follows: $(\mathrm{N}>50+8 \times 5=40)=$ minimum 90 vendors were required to participate in this study. Second determination of sample size can be based on population. According to Krejcie and Morgan (1970), they mentioned for a population of 800 , the minimum sample size required is 260 . Hence, the sample size in this study has acceptable number.

Table 1

The profile respondents $(\mathrm{n}=300)$

\begin{tabular}{lcc}
\hline Construct/measures & Frequency & Percent \\
\hline Vendor tier & & 75.7 \\
Tier_1 & 227 & 16.7 \\
Tier_2 & 50 & 7.7 \\
Tier_3 & 23 & 40.7 \\
Ownership status & 122 & 12.7 \\
Bumi & 38 & 36.3 \\
Non_bumi & 109 & 10.3 \\
MNC & 31 & 10.0 \\
Foreign & & 19.3 \\
Module manufactured & 30 & 21.3 \\
Body & 58 & 40.7 \\
Chasis & 64 & 8.7 \\
Electrical & 122 & 28.0 \\
Equipment & 26 & 61.0 \\
Powertrain & & 11.0 \\
Types market penetrate & 84 & 183 \\
REM & 33 & \\
OEM & & \\
OBM & & \\
\hline
\end{tabular}


Lastly, the determination of sample size used in this study are based on $1 \%, 5 \%$ or $10 \%$ allowable error. For a population of 800 vendors, based on allowable sample size error $5 \%$, minimum sample size required is only 243. After a period of six months a total of 300 questionnaires were obtained and used for the analysis. The background of the respondents are reported as in Table 1. All the respondents completing the questionnaire were consists of Tier-1 vendor $(75.7 \%)$, from the top (52\%) or middle management (48\%). The firms surveyed are distributed among the sectors included as follows: textile (20\%), chemical $(18 \%)$, metal products $(19 \%)$, machinery $(15 \%)$, domestic appliances $(8 \%)$ and automotive industries $(20 \%)$.

\section{Results and discussion}

The study used Structural Equation Modelling (SEM) method which is a second-generation multivariate data analysis. It is often used by many social science researchers because it allows complex analysis of the relationship among multiple variables (Kwong 2013; Hair et al., 2017). In this study, Smart PLS 3 software was used in analysing the complex multivariate analysis. In Smart PLS 3, the evaluation of SEM process consist of two assessment models which are the assessment of reflective measurement model and assessment of structural model. In the first model, the reflective measurement model was tested by performing validity and reliability test.

\subsection{Descriptive analysis}

In order to ensure instrument quality, data were analysed for its validity. Standard deviation and mean for all the constructs are shown in Table 2. All items in the questionnaire were asked with 5-point Likert scale with scoring ranging from 5 (strongly agree) to 1 (strongly disagree). Construct product innovation recorded the highest mean value of 4.06 and investment strategy recorded the highest value for standard deviation of 1.083 .

\section{Table 2}

Descriptive and Measurement Assessment Results

\begin{tabular}{|c|c|c|c|c|c|c|c|}
\hline Constructs & Items & Factor Loading & Mean & SD & Cronbach's & $\mathrm{CR}$ & AVE \\
\hline \multirow[t]{6}{*}{ NAP } & NAP1 & 0.704 & 3.083 & 1.083 & \multirow{6}{*}{0.817} & \multirow{6}{*}{0.868} & \multirow{6}{*}{0.523} \\
\hline & NAP2 & 0.680 & 3.723 & 0.633 & & & \\
\hline & NAP3 & 0.738 & 4.007 & 0.863 & & & \\
\hline & NAP4 & 0.786 & 4.030 & 0.712 & & & \\
\hline & NAP5 & 0.732 & 3.553 & 0.723 & & & \\
\hline & NAP6 & 0.695 & 3.980 & 0.725 & & & \\
\hline \multirow[t]{3}{*}{ ORI } & ORI1 & 0.825 & 3.653 & 0.731 & \multirow[t]{3}{*}{0.779} & \multirow[t]{3}{*}{0.872} & \multirow[t]{3}{*}{0.696} \\
\hline & ORI2 & 0.906 & 3.710 & 0.809 & & & \\
\hline & ORI3 & 0.765 & 3.840 & 0.562 & & & \\
\hline \multirow[t]{4}{*}{ PCI } & PCI1 & 0.692 & 3.933 & 0.733 & \multirow{4}{*}{0.804} & \multirow{4}{*}{0.873} & \multirow{4}{*}{0.633} \\
\hline & PCI2 & 0.796 & 3.520 & 0.706 & & & \\
\hline & $\mathrm{PCI} 3$ & 0.840 & 3.847 & 0.682 & & & \\
\hline & PCI4 & 0.844 & 3.870 & 0.758 & & & \\
\hline \multirow[t]{3}{*}{ PDI } & PDI1 & 0.825 & 3.793 & 0.872 & \multirow{3}{*}{0.816} & \multirow{3}{*}{0.890} & \multirow{3}{*}{0.729} \\
\hline & PDI2 & 0.823 & 3.883 & 0.710 & & & \\
\hline & PDI3 & 0.910 & 4.060 & 0.715 & & & \\
\hline \multirow[t]{4}{*}{ MKI } & MKI1 & 0.799 & 3.567 & 0.796 & \multirow{4}{*}{0.793} & \multirow{4}{*}{0.863} & \multirow{4}{*}{0.613} \\
\hline & MKI2 & 0.812 & 3.387 & 0.860 & & & \\
\hline & MKI3 & 0.818 & 3.493 & 0.962 & & & \\
\hline & MKI4 & 0.695 & 3.047 & 1.056 & & & \\
\hline \multirow[t]{4}{*}{ INP } & INP1 & 0.658 & 3.883 & 0.836 & \multirow{4}{*}{0.796} & \multirow{4}{*}{0.867} & \multirow{4}{*}{0.621} \\
\hline & INP2 & 0.877 & 3.850 & 0.685 & & & \\
\hline & INP3 & 0.815 & 3.517 & 0.840 & & & \\
\hline & INP4 & 0.787 & 3.793 & 0.702 & & & \\
\hline \multirow[t]{4}{*}{ MKP } & MKP1 & 0.794 & 3.713 & 0.725 & \multirow{4}{*}{0.798} & \multirow{4}{*}{0.867} & \multirow{4}{*}{0.620} \\
\hline & MKP2 & 0.781 & 3.680 & 0.748 & & & \\
\hline & MKP3 & 0.775 & 3.707 & 0.732 & & & \\
\hline & MKP4 & 0.801 & 3.760 & 0.661 & & & \\
\hline \multirow[t]{3}{*}{ FP } & FP1 & 0.861 & 3.233 & 1.053 & & & \\
\hline & FP2 & 0.928 & 3.627 & 0.877 & 0.710 & 0.834 & 0.636 \\
\hline & FP3 & 0.552 & 3.300 & 0.973 & & & \\
\hline
\end{tabular}


The assessment of reflective model consists of internal consistency, convergent validity and discriminant validity. In the past, only Cronbach's alpha was used in measuring internal consistency. In Smart PLS, the internal consistency can be measured by Cronbach's alpha, composite reliability (CR) and average variance extracted (AVE). Cronbach's alpha and CR of more than 0.7 is accepted as satisfactory (Hair et al., 2017). As for the convergent validity is measured by Average Variance Extracted (AVE) with AVE $>0.5$ is accepted. The result of the reliability and validity test for the model is presented as in Table 2 .

From the results, all the measurement for internal consistency are acceptable. The Cronbach's alpha coefficient in this research is range between 0.710 and 0.817 . The CR value, all the constructs in this research is range between 0.834 and 0.872 . Both the measurement for internal consistency are accepted because exceeded the minimum requirement of 0.7 . The convergent validity for the all the constructs in this research is also acceptable. The AVE value range between 0.523 to 0.729 which is above than 0.5 and acceptable.

After all the internal consistency tests were validated, discriminant validity test were conducted with the following test which are cross-loadings, Fornell-Lacker and heterotrait-monotrait ratios (HTMT). The output for cross loading between constructs and indicators were illustrated in Table 3 . The cross loadings result shows all item's loading for the respective sub-constructs is the highest item loading compare with other items loading. The result of the cross loading confirmed all the thirty one items indicators belong to the right indicator.

Table 3

Cross Loadings Results

\begin{tabular}{|c|c|c|c|c|c|c|c|c|}
\hline & $\mathrm{FP}$ & NAP & INP & MKI & MKP & ORI & PCI & PDI \\
\hline FP1 & 0.861 & 0.294 & 0.457 & 0.289 & 0.550 & 0.225 & 0.256 & 0.477 \\
\hline FP2 & 0.928 & 0.274 & 0.576 & 0.385 & 0.745 & 0.178 & 0.367 & 0.478 \\
\hline FP3 & 0.852 & 0.149 & 0.273 & 0.233 & 0.291 & 0.066 & 0.185 & 0.258 \\
\hline NAP1 & 0.253 & 0.704 & 0.328 & 0.308 & 0.299 & 0.214 & 0.291 & 0.417 \\
\hline NAP2 & 0.298 & 0.680 & 0.296 & 0.235 & 0.317 & 0.251 & 0.355 & 0.361 \\
\hline NAP3 & 0.277 & 0.738 & 0.289 & 0.272 & 0.311 & 0.245 & 0.327 & 0.361 \\
\hline NAP4 & 0.242 & 0.786 & 0.237 & 0.242 & 0.268 & 0.198 & 0.352 & 0.371 \\
\hline NAP5 & 0.187 & 0.732 & 0.317 & 0.233 & 0.300 & 0.355 & 0.357 & 0.417 \\
\hline NAP6 & 0.054 & 0.695 & 0.124 & 0.163 & 0.107 & 0.318 & 0.274 & 0.243 \\
\hline INP1 & 0.196 & 0.101 & 0.658 & 0.390 & 0.233 & 0.321 & 0.367 & 0.346 \\
\hline INP2 & 0.558 & 0.362 & 0.877 & 0.523 & 0.494 & 0.476 & 0.450 & 0.574 \\
\hline INP3 & 0.335 & 0.267 & 0.815 & 0.397 & 0.316 & 0.397 & 0.364 & 0.370 \\
\hline INP4 & 0.612 & 0.385 & 0.787 & 0.449 & 0.490 & 0.339 & 0.489 & 0.519 \\
\hline MKI1 & 0.341 & 0.389 & 0.446 & 0.799 & 0.351 & 0.456 & 0.572 & 0.548 \\
\hline MKI2 & 0.248 & 0.185 & 0.492 & 0.812 & 0.302 & 0.318 & 0.315 & 0.421 \\
\hline MKI3 & 0.390 & 0.293 & 0.491 & 0.818 & 0.427 & 0.388 & 0.509 & 0.585 \\
\hline MKI4 & 0.190 & 0.137 & 0.295 & 0.695 & 0.188 & 0.074 & 0.267 & 0.259 \\
\hline MKP1 & 0.667 & 0.347 & 0.461 & 0.418 & 0.794 & 0.214 & 0.367 & 0.454 \\
\hline MKP2 & 0.433 & 0.367 & 0.395 & 0.248 & 0.781 & 0.154 & 0.217 & 0.326 \\
\hline MKP3 & 0.575 & 0.193 & 0.357 & 0.269 & 0.775 & 0.216 & 0.284 & 0.373 \\
\hline MKP4 & 0.526 & 0.281 & 0.378 & 0.368 & 0.801 & 0.142 & 0.240 & 0.363 \\
\hline ORI1 & 0.214 & 0.307 & 0.394 & 0.303 & 0.097 & 0.825 & 0.473 & 0.362 \\
\hline ORI2 & 0.183 & 0.330 & 0.445 & 0.405 & 0.182 & 0.906 & 0.658 & 0.504 \\
\hline ORI3 & 0.120 & 0.273 & 0.386 & 0.362 & 0.315 & 0.765 & 0.398 & 0.424 \\
\hline PCI1 & 0.308 & 0.392 & 0.355 & 0.306 & 0.221 & 0.393 & 0.692 & 0.620 \\
\hline PCI2 & 0.273 & 0.353 & 0.502 & 0.560 & 0.294 & 0.454 & 0.796 & 0.507 \\
\hline PCI3 & 0.255 & 0.379 & 0.374 & 0.423 & 0.314 & 0.540 & 0.840 & 0.525 \\
\hline PCI4 & 0.286 & 0.321 & 0.456 & 0.448 & 0.313 & 0.578 & 0.844 & 0.541 \\
\hline PDI1 & 0.439 & 0.430 & 0.618 & 0.630 & 0.382 & 0.548 & 0.626 & 0.825 \\
\hline PDI2 & 0.414 & 0.392 & 0.373 & 0.410 & 0.418 & 0.329 & 0.507 & 0.823 \\
\hline PDI3 & 0.481 & 0.469 & 0.484 & 0.477 & 0.455 & 0.414 & 0.609 & 0.910 \\
\hline
\end{tabular}

The results of Fornell-Lacker are illustrated in the bolded elements in Table 4. The bolded element represent the square roots of the AVE and non-bolded values represent the inter correlation value between 
constructs, all off-diagonal elements are lower than square roots of AVE (bolded on the diagonal). Hence, the result confirmed that the Fornell and Larker's criterion is met.

Table 4

Fornell-Lacker criterion result

\begin{tabular}{cccccccc}
\hline & FP & INP & MKI & MKP & NAP & ORI & PCI \\
\hline FP & $\mathbf{0 . 7 9 7}$ & & & & & \\
INP & 0.573 & $\mathbf{0 . 7 8 8}$ & & & & \\
MKI & 0.387 & 0.564 & $\mathbf{0 . 7 8 3}$ & 0.422 & $\mathbf{0 . 7 8 8}$ & & \\
MKP & 0.711 & 0.509 & 0.338 & 0.377 & $\mathbf{0 . 7 2 3}$ & \\
NAP & 0.308 & 0.375 & 0.428 & 0.234 & 0.365 & $\mathbf{0 . 8 3 4}$ \\
ORI & 0.208 & 0.491 & 0.554 & 0.360 & 0.454 & 0.618 \\
PCI & 0.353 & 0.536 & 0.605 & 0.488 & 0.507 & 0.518 \\
PDI & 0.523 & 0.591 & & & $\mathbf{0 . 7 9 5}$ & 0.688 \\
\hline
\end{tabular}

Lastly the discriminant validity was checked based on HTMT ratios of correlations. The HTMT result is illustrated in Table 5 show it is acceptable for all the indicators. Firstly, the HTMT values are within the confidence interval. Secondly the HTMT values are found to be above 0.90 (Gold et al., 2001) and above 0.85 (Kline, 2010).

Table 5

Heterotrait-Monotrait Ratio (HTMT)

\begin{tabular}{|c|c|c|c|c|c|c|c|c|}
\hline & $\mathrm{FP}$ & INP & MKI & MKP & NAP & ORI & PCI & PDI \\
\hline \multicolumn{9}{|l|}{ FP } \\
\hline INP & 0.683 & & & & & & & \\
\hline MKI & 0.489 & 0.685 & & & & & & \\
\hline MKP & 0.870 & 0.605 & 0.496 & & & & & \\
\hline NAP & 0.387 & 0.449 & 0.393 & 0.459 & & & & \\
\hline ORI & 0.263 & 0.618 & 0.501 & 0.297 & 0.457 & & & \\
\hline PCI & 0.448 & 0.658 & 0.655 & 0.438 & 0.558 & 0.775 & & \\
\hline PDI & 0.664 & 0.694 & 0.702 & 0.597 & 0.608 & 0.630 & 0.843 & \\
\hline
\end{tabular}

\subsection{Assessment of Structural Model}

After the assessment of reflective measurement model, the study proceeded with the assessment of the structural model. The assessment was performed with the following assessment which are; lateral collinearity, path coefficient and coefficient of determination tests. For lateral collinearity, the inner VIF (Variance Inflator Factor) should be less than 3.3 according to Diamantopoulous (2006) and less than 5.0 Hair et al. (2017). All the VIF values for thirty one constructs are range between 1.306 and 2.926 thus suggested acceptable collinearity. For path coefficient, bootstrapping procedure was conducted on subsamples of 2000 taken from the original sample to determine bootstrap standard error. In other words, the results from the bootstrapping procedure confirm the normality of data. Coefficient of determination score $\left(\mathrm{R}^{2}\right)$ measures the model's predictive accuracy. It is also combined the effect of exogenous variables on endogenous variables. In other words, $\left(\mathrm{R}^{2}\right)$ represents the amount of variance in the endogenous variable. The effect ranges from 0 to 1 with higher values indicates higher level of predictive accuracy. According to Cohen (1989), $\left(\mathrm{R}^{2}\right)$ value of 0.26 is substantial, 0.13 is moderate and 0.02 is weak. Hair et al. (2017) identified 0.75 is substantial, 0.5 is moderate and 0.25 is weak. Thus the higher the $\mathrm{R}^{2}$ values, the better the construct is explained by the latent variables in the structural model that point at it via structural model path relationships. The assessment of coefficient of determination is given as in Fig. 2. 


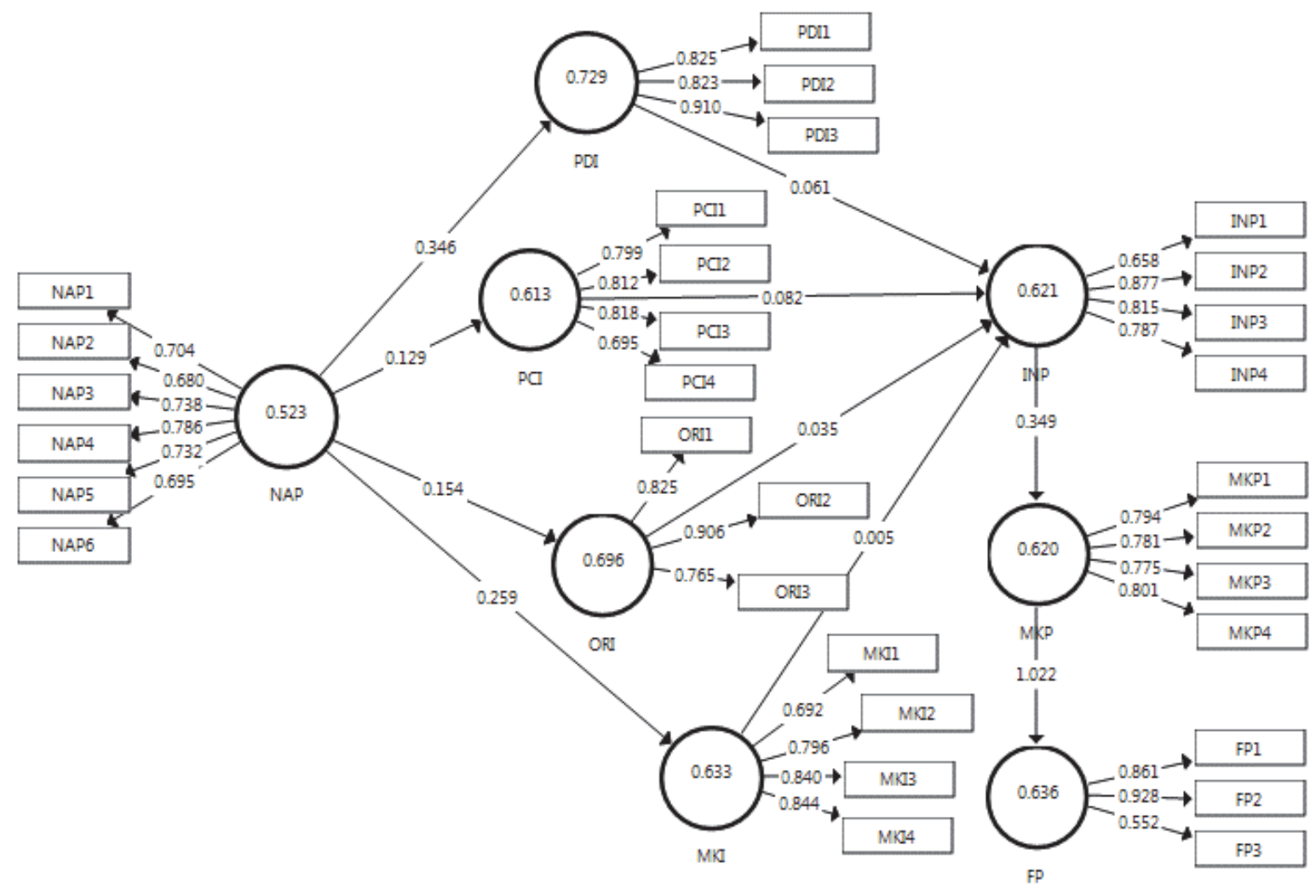

Key: NAP: National Automotive Policy, PDI: product innovation, PCI: process innovation, MKI: market innovation, ORI: organization innovation, INP: innovative performance, MKP: market performance, FP: financial performance

Fig. 3. PLS algorithm results

\subsubsection{Hypothesis Tests}

Fig. 3 and also Table 6 show structural modelling assessments that display the findings of the testing of various hypotheses and all hypotheses are confirmed. From the results of Table 6, the NAP strategies supported all the elements of innovation to vendor's performance except in one indirect relationship hypothesis. In direct relationship between NAP and innovation, H1a which is NAP predicts product innovation is acceptable because $(\beta=0.51, \mathrm{t}=11.812, \mathrm{p}<0.001)$. NAP also meaningfully predicts the other three types of innovation which are process innovation, market innovation and organization innovation with H1b, H1c and H1d correspondingly confirmed with $(\beta=0.459, \mathrm{t}=10.183, \mathrm{p}<0.001),(\beta=$ $0.342, \mathrm{t}=6.146, \mathrm{p}<0.001)$ and $(\beta=0.371, \mathrm{t}=6.575, \mathrm{p}<0.001)$. In the indirect relationship, one hypothesis i.e. H2b was found not significant. The other three types of innovation were found to be meaningfully mediated between NAP and innovation performance which are product innovation, market innovation and organization innovation. Therefore, $\mathrm{H} 2 \mathrm{a}, \mathrm{H} 2 \mathrm{c}$ and $\mathrm{H} 2 \mathrm{~d}$ are correspondingly confirmed with $(\beta=0.282, \mathrm{t}=3.865, \mathrm{p}<0.001),(\beta=0.275, \mathrm{t}=4.62, \mathrm{p}<0.001)$ and $(\beta=0.177, \mathrm{t}=2.607, \mathrm{p}<0.001)$. As for hypothesis $\mathrm{H} 3$ and $\mathrm{H} 4$, innovation performance meaningfully predicts market performance, and therefore $\mathrm{H} 3$ is confirmed with $(\beta=0.514, \mathrm{t}=9.597, \mathrm{p}<0.001)$, whereas market performance meaningfully predicts impacts on financial performance, and hence $\mathrm{H} 4$ is accepted with $(\beta=0.725, \mathrm{t}=24.776$, $\mathrm{p}<0.001)$.

According to Baron and Kenny(1986) a variable can be regarded as mediator if the following criteria are met: (1) Predictor variables must be capable of predicting outcome variables without mediators; (2) 
Predictor variables must be capable of predicting mediators; (3) Mediator variables must be capable of predicting outcome variables; and (4) Predictor variables should not effectually predict outcome variables whenever mediators are influenced in the model. Hair et al. (2017) mentioned researchers test the mediating effects, they have to bootstrap the sample distribution for all the indirect and direct effects. The bootstrapping technique does not presume the shapes or statistics of the variable distributions and can be confidently applied to smaller sample sizes. Thus, this approach displays better statistical power in comparison to the Sobel test. This study tested the mediatory effect using the bootstrapping procedure with a sample size of 1000 which bootstraps all the indirect effects.

Table 6

Structural assessment result

\begin{tabular}{|c|c|c|c|c|c|c|c|c|c|c|c|c|}
\hline $\begin{array}{l}\text { Hypo } \\
\text { thesis }\end{array}$ & Relationship & $\begin{array}{c}\text { Std } \\
\text { Beta }\end{array}$ & $\begin{array}{c}\text { Std } \\
\text { Error }\end{array}$ & $\begin{array}{c}\mathrm{t}- \\
\text { value }\end{array}$ & $\begin{array}{c}\mathrm{p}- \\
\text { value }\end{array}$ & LL & UL & Decision & $\mathrm{R}^{2}$ & $\mathrm{f}^{2}$ & $\mathrm{Q}^{2}$ & VIF \\
\hline H1a & $\mathrm{NAP} \rightarrow \mathrm{PDI}$ & 0.507 & 0.041 & 12.494 & 0.000 & 0.414 & 0.575 & Supported & 0.507 & 0.346 & 0.259 & 1.306 \\
\hline $\mathrm{H} 1 \mathrm{~b}$ & $\mathrm{NAP} \rightarrow \mathrm{PCI}$ & 0.338 & 0.053 & 6.347 & 0.000 & 0.217 & 0.426 & Supported & 0.454 & 0.259 & 0.216 & 1.562 \\
\hline $\mathrm{H} 1 \mathrm{c}$ & $\mathrm{NAP} \rightarrow \mathrm{MKI}$ & 0.454 & 0.044 & 10.289 & 0.000 & 0.354 & 0.53 & Supported & 0.338 & 0.129 & 0.414 & 2.361 \\
\hline H1d & $\mathrm{NAP} \rightarrow \mathrm{ORI}$ & 0.365 & 0.054 & 6.746 & 0.000 & 0.247 & 0.455 & Supported & 0.365 & 0.154 & 0.191 & 2.400 \\
\hline $\mathrm{H} 2 \mathrm{a}$ & $\mathrm{PDI} \rightarrow \mathrm{INP}$ & 0.274 & 0.075 & 3.642 & 0.000 & 0.119 & 0.414 & Supported & 0.274 & 0.061 & 0.187 & 1.531 \\
\hline $\mathrm{H} 2 \mathrm{~b}$ & $\mathrm{PCI} \rightarrow \mathrm{INP}$ & 0.275 & 0.063 & 4.357 & 0.000 & 0.146 & 0.399 & Supported & 0.275 & 0.082 & 0.105 & 2.926 \\
\hline $\mathrm{H} 2 \mathrm{c}$ & $\mathrm{MKI} \rightarrow \mathrm{INP}$ & 0.084 & 0.088 & 0.953 & 0.341 & -0.092 & 0.257 & Not Supported & 0.084 & 0.005 & 1.702 & 2.367 \\
\hline $\mathrm{H} 2 \mathrm{~d}$ & $\mathrm{ORI} \rightarrow \mathrm{INP}$ & 0.179 & 0.067 & 2.691 & 0.007 & 0.032 & 0.299 & Supported & 0.179 & 0.035 & 0.216 & 1.562 \\
\hline $\mathrm{H} 3$ & $\mathrm{INP} \rightarrow \mathrm{MKP}$ & 0.509 & 0.055 & 9.325 & 0.000 & 0.394 & 0.604 & Supported & 0.509 & 0.349 & 0.266 & 2.361 \\
\hline $\mathrm{H} 4$ & $\mathrm{MKP} \rightarrow \mathrm{FP}$ & 0.711 & 0.028 & 25.805 & 0.000 & 0.642 & 0.753 & Supported & 0.711 & 1.022 & 0.289 & 2.288 \\
\hline
\end{tabular}

The findings from bootstrapping analyses are shown in Table 6 and show the results of lower limit (LL) values and upper limit values (UL). In order for the indirect relationship to be significant in mediation, the LL and UL should not contain value of zero between the LL and UL values.

$\mathrm{H} 2 \mathrm{a}, \mathrm{H} 2 \mathrm{~b}$ and $\mathrm{H} 2 \mathrm{~d}$ were found indirectly influence innovation performance with the method of Preacher and Hayes (2008) indicating the trend, with 0.274, 95\% Boot CI: [LL $=0.119$, UL $=0.414]$, as not overlapping zero in-between the values that specify for mediation. It was therefore determined that product innovation has a meaningful mediating effect between NAP and innovation performance, and therefore $\mathrm{H} 2 \mathrm{a}$ is confirmed. The indirect influence of NAP on innovation performance via marketing innovation and with $\beta=0.08$ is not meaningful with its t-value equal to 0.953 and [ $\mathrm{LL}=-0.09, \mathrm{UL}=0.257$ ], the indirect relationship is not significant mediated since its overlap zero in-between the values, which indicates there is no mediation for H2c. The indirect influence of NAP on innovation performance via organization innovation where $\beta=0.179$ is meaningful with its t-value equal to 2.691 with $0.067,95 \%$ Boot CI: $[\mathrm{LL}=0.032, \mathrm{UL}=0.299]$, the trend does not overlap zero between the values, which shows a mediating effect. The mediating influence of the organization innovation thus has a meaningful relationship between NAP and impacts on innovation performance, and therefore $\mathrm{H} 2 \mathrm{~d}$ is confirmed. The direct result of innovation performance to $\mathrm{H} 3$ market performance was found to be meaningful with $\beta=0.509$, $\mathrm{t}$-value equal to 9.325and [LL $=0.394, \mathrm{UL}=0.604]$. The direct result of market performance to financial performance was found to be meaningful with $\beta=0.711$, t-value equal to 25.805 and [LL $=0.642$, UL $=0.753]$. The $R^{2}$ values feature acceptable levels of explanatory power of exogenous variable in this study (Chin, 1998; Ramayah, 2018 ). From the result, all the strategies in NAP have given an acceptable of explanatory power. NAP ables to describe all the innovation types in the study. NAP explains $50.7 \%$ of the variation to product innovation, process innovation is explained by NAP for $45.4 \%$, market innovation and organization are explained by $33.8 \%$ and $36.5 \%$ respectively. As for the second hypothesis, innovative performance explained product innovation, process innovation, market innovation and organization innovati for about $27.4 \%, 8.4 \%, 27.5 \%$ and $17.9 \%$, respectively. Process innovation showed the lowest explanatory power for $R^{2}$. For market performance was explained about $50.9 \%$ and financial performance was explained very well with market performance of about $71.1 \%$. 
Effects sizes $\left(\mathrm{f}^{2}\right)$ were examined in this study to determine the impact of exogenous latent constructs (whether weak, moderate, or substantial) on endogenous latent constructs (Gefen et al., 2000). The obtained $\mathrm{f}^{2}$ value of 0.35 denotes large effect, 0.15 denotes medium effect, and 0.02 denotes small effect (Cohen, 1988). Table 6 shows all $\mathrm{f}^{2}$ results according to effects sizes: three relationships (large), two (medium), and all remaining associations (small). In the assessment of predictive relevance for the proposed research model, the researchers implemented the blindfolding technique. This method is best utilised on endogenous constructs using only reflective measurements (Ramayah, 2018).

According to Hair et al. (2017) certain endogenous constructs of suggested models will have predictive relevance if their values of $Q^{2}$ exceed zero. In this research, every $Q^{2}$ value was established as non-zero, therefore it may be concluded that our suggested model does feature acceptable predictive relevance (see Table 6). Relative measures of predictive relevance are denoted by $Q^{2}$ values of 0.02 (small), 0.15 (medium), and 0.35 (large). In this research, one particular endogenous construct was established with large predictive relevance, whereas the others presented medium values. Based on O'Brien (2007), multicollinearity presents a problem, for it points to an overlapping of variances that exogenous constructs will describe in terms of endogenous constructs. Consequently, each variance cannot be justified in its presence, in terms of the endogenous variable. The variance inflation factor (VIF) is broadly utilised in measurements to determine the degree of multicollinearity present (O'brien, 2007). A value exceeding 10 for the largest VIF indicates a problem (Myers, 1990; Bowerman \& O'Connell, 1990). Meanwhile, Hair et al. (2017) suggested that a value exceeding 5 for the largest VIF indicates a multicollinearity problem. Based on these two measurement, the VIF values for all the construct are acceptable because they range between 1.306 and 2.926 .

\section{Discussion}

This research established that government support such as in the NAP strategies still provide meaningful and positive effects to vendor's innovation. The research hypothesis supported previous studies findings: government support gave positive effect to product innovation and process innovation (Govindaraju et al., 2013; Zhang et al., 2017; Zhang et al. 2019). The study also confirmed innovative performance is the important indicator for vendor's performance acted as mediator between innovation types and market performance and financial performance. The findings show NAP positively influenced all innovation performance, market performance and financial performance. However in the indirect relationship, market innovation was found not significant to innovative performance. Findings from the research show product and process innovation are still found to be significant and critical in high technology industry like in the automotive sector. Repeated process and learning among vendor were found to be the important aspect in the vendor's performance. Nevertheless, marketing and organization innovation are found to be significant in some studies. The insignificant effect of marketing innovation on firm performance may be due to the fact that most of the automotive supplier firms in the sample do not have a corporate marketing department in their organizations.

\section{Conclusion}

NAP strategies were perceived as positively significant to product innovation, process innovation and organization innovation. The study only focused on the effect of government policy towards innovation types and performance. Future research should include firm size and ownership in the study since foreign ownership was found to give significant positive effect to vendor's performance. Therefore the researchers suggest that in future research with bigger sample size in order to get positive significant result. The National Automotive Policy has set up a good direction for Malaysia automotive ecosystem. With the correct government strategies, innovation and performance can be improved. 


\section{References}

Abiodun, B. Y. (2014). The prospects of accounting and economic systems in the era of global knowledge economy. The Economics and Finance Letters, 1(2), 9-14.

Ahmed, A., Rehan, R., Chhapra, I. U., \& Supro, S. (2018). Interest rate and financial performance of banks in Pakistan. International Journal of Applied Economics, Finance and Accounting, 2(1), 1-7.

Ahmed, U., Majid, A. H. A., \& Zin, M. L. M. (2016). HR Moderating HR: Critical link between Developmental HR Practices and work engagement in a Moderated Model. Management Review: An International Journal, 11(2), 4.

Alam, S. S., Arumugam, V., Nor, N. G. M., Kaliappan, P., \& Fang, L. S. (2013). Relationships between innovation capabilities, business performance, marketing performance and financial performance: A literature review. Business and Management Horizons, 1(1), 59-73.

Ao, S. I., \& Gelman, L. (Eds.). (2012). Electrical engineering and intelligent systems (Vol. 130). Springer Science \& Business Media.

Ali, A., \& Haseeb, M. (2019). Radio frequency identification (RFID) technology as a strategic tool towards higher performance of supply chain operations in textile and apparel industry of Malaysia. Uncertain Supply Chain Management, 7(2), 215-226.

ASEAN Secretariat. (2014). ASEAN Investment Report 2013-2014: FDI Development and Regional Value Chains.

Atalay, M., Anafarta, N., \& Sarvan, F. (2013). The relationship between innovation and firm performance: An empirical evidence from Turkish automotive supplier industry. Procedia-Social and Behavioral Sciences, 75, 226-235.

Barnes, J., Kaplinsky, R., \& Morris, M. (2004). Industrial policy in developing economies: Developing dynamic comparative advantage in the South African automobile sector. Competition \& Change, 8(2), 153-172.

Baron, R. M., \& Kenny, D. A. (1986). The moderator-mediator variable distinction in social psychological research: Conceptual, strategic, and statistical considerations. Journal of personality and social psychology, 51(6), 1173.

Bell, E., Bryman, A., \& Harley, B. (2018). Business research methods. Oxford university press.

Chang, H. J. (2010). Bad Samaritans: The myth of free trade and the secret history of capitalism. Bloomsbury Publishing USA.

Chidoko, C., \& Mashavira, N. (2014). An analysis of corporate governance in the banking sector of Zimbabwe. Humanities and Social Sciences Letters, 2(3), 174-180.

Chin, W. W. (1998). The partial least squares approach to structural equation modeling. Modern methods for business research, 295(2), 295-336.

DeVon, H. A., Block, M. E., Moyle-Wright, P., Ernst, D. M., Hayden, S. J., Lazzara, D. J., ... \& KostasPolston, E. (2007). A psychometric toolbox for testing validity and reliability. Journal of Nursing scholarship, 39(2), 155-164.

Diemer, A., Nedelciu, E., Schellens, M., \& Gisladottir, J. (2018). Challenges for Sustainability in Critical Raw Material Assessments. International Journal of Management and Sustainability, 7(3), 156-179.

Elkhayat, N., \& ElBannan, M. A. (2018). State Divestitures and Bank Performance: Empirical Evidence from the Middle East and North Africa Region. Asian Economic and Financial Review, 8(2), 145.

Forgha, G., Serge, T., \& Ajong, N. (2018). Effects of Lending Relationship on the Interest Rates of Commercial Banks in Cameroon. Asian Journal of Economic Modelling, 6(2), 208-219.

Freeman, C. (1995). The 'National System of Innovation'in historical perspective. Cambridge Journal of economics, 19(1), 5-24.

Gefen, D., Straub, D., \& Boudreau, M. C. (2000). Structural equation modeling and regression: Guidelines for research practice. Communications of the association for information systems, 4(1), 7.

Chandran Govindaraju, V. G. R., Krishnan Vijayaraghavan, G., \& Pandiyan, V. (2013). Product and process innovation in Malaysian manufacturing: The role of government, organizational innovation and exports. Innovation, 15(1), 52-68. 
Guan, J., \& Yam, R. C. (2015). Effects of government financial incentives on firms' innovation performance in China: Evidences from Beijing in the 1990s. Research Policy, 44(1), 273-282.

Gunday, G., Ulusoy, G., Kilic, K., \& Alpkan, L. (2011). Effects of innovation types on firm performance. International Journal of production economics, 133(2), 662-676.

Hair Jr, J. F., Hult, G. T. M., Ringle, C., \& Sarstedt, M. (2016). A primer on partial least squares structural equation modeling (PLS-SEM). Sage publications.

Hallunovi, A., \& Berdo, M. (2018). The Relationship between Risk Management and Profitability of Commercial Banks in Albania. Asian Themes in Social Sciences Research, 1(2), 44-49.

Hang, H. T. T., Vy, P. D., \& Bandaralage, J. (2016). Mergers, acquisitions and market concentration in the banking sector: The case of Vietnam. Asian Journal of Economics and Empirical Research, 3(1), 49-58.

Haseeb, M., Abidin, I. S. Z., Hye, Q. M. A., \& Hartani, N. H. (2018). The impact of renewable energy on economic well-being of Malaysia: Fresh evidence from auto regressive distributed lag bound testing approach. International Journal of Energy Economics and Policy, 9(1), 269-275.

Haseeb, M., Zandi, G., Hartani, N. H., Pahi, M. H., \& Nadeem, S. (2019). Environmental Analysis of the Effect of Population Growth Rate on Supply Chain Performance and Economic Growth of Indonesia. Ekoloji, 28(107), 417-426.

Hagedoorn, J., \& Cloodt, M. (2003). Measuring innovative performance: is there an advantage in using multiple indicators?. Research policy, 32(8), 1365-1379.

Jugend, D., Jabbour, C. J. C., Scaliza, J. A. A., Rocha, R. S., Junior, J. A. G., Latan, H., \& Salgado, M. H. (2018). Relationships among open innovation, innovative performance, government support and firm size: Comparing Brazilian firms embracing different levels of radicalism in innovation. Technovation, 74, 54-65.

Kadasala, N. R., Narayanan, B., \& Liu, Y. (2016). International Trade Regulations on BPA: Global Health and Economic Implications. Asian Development Policy Review, 4(4), 134-142.

Kalay, F., \& Lynn, G. (2015). The impact of strategic innovation management practices on firm innovation performance. Research Journal of Business and Management, 2(3), 412-429.

Karabulut, A. T. (2015). Effects of innovation types on performance of manufacturing firms in Turkey. Procedia-Social and Behavioral Sciences, 195, 1355-1364.

Karlsson, C., \& Tavassoli, S. (2015). Innovation strategies and firm performance. Centre of Excellence for Science and Innovation Studies Working Paper Series, 401.

Khan, S. N., \& Ali, E. I. E. (2017). The moderating role of intellectual capital between enterprise risk management and firm performance: A conceptual review. American Journal of Social Sciences and Humanities, 2(1), 9-15.

Wong, K. K. K. (2013). Partial least squares structural equation modeling (PLS-SEM) techniques using SmartPLS. Marketing Bulletin, 24(1), 1-32.

MIDA. (2012). Malaysia's Automotive Industry. MIDA.

MITI. (2014). NAP 2014.

Natsuda, K., \& Thoburn, J. (2014). How much policy space still exists under the WTO? A comparative study of the automotive industry in Thailand and Malaysia. Review of International Political Economy, 21(6), 1346-1377.

Nze, I. C., Ogwude, I. C., Nnadi, K. U., \& Ibe, C. C. (2016). Modelling the relationship between demand for river port services and vessel supply costs: Empirical evidence from Nigeria. Global Journal of Social Sciences Studies, 2(3), 144-149.

Obodo, N. A. (2018). Content Analysis of Time Management as a Tool for Corporate Effectiveness. International Journal of Applied Economics, Finance and Accounting, 2(2), 36-39.

OECD. (2005). Oslo Manual.

Owusu-Antwi, G., Banerjee, R., \& Antwi, J. (2017). Interest rate spread on bank profitability: The case of Ghanaian banks. Journal of Accounting, Business and Finance Research, 1(1), 34-45.

Panayides, P. M., \& Lun, Y. V. (2009). The impact of trust on innovativeness and supply chain performance. International Journal of Production Economics, 122(1), 35-46.

Porter, M. E. (1990). The Competitive Advonioge of Notions. Harvard business review. 
Rajapathirana, R. J., \& Hui, Y. (2018). Relationship between innovation capability, innovation type, and firm performance. Journal of Innovation \& Knowledge, 3(1), 44-55.

Ranawat, M., \& Tiwari, R. (2009). Influence of government policies on industry development: The case of India's automotive industry. Technology and Innovation Management (University of Hamburg) Working Paper, (57).

Rousseau, M. B., Mathias, B. D., Madden, L. T., \& Crook, T. R. (2016). Innovation, firm performance, and appropriation: A meta-analysis. International Journal of Innovation Management, 20(03), 1650033.

Sabri, T. B. H., \& Sweis, K. M. (2015). The impact of the global financial crisis on the debt, liquidity, growth, and volume of companies in palestine stock exchange. Journal of Social Economics Research, 2(2), 31-37.

Abidin, A. S. Z., Muslimen, R., Yusuff, R. M., Zulkifli, N., Ismail, M. Y., \& Bakar, N. A. (2012). An exploratory study on the critical success factors for design capabilities development. Operations and supply chain management, 5(1), 14-26.

Segawa, N., Natsuda, K., \& Thoburn, J. (2014). Affirmative action and economic liberalisation: the dilemmas of the Malaysian automotive industry. Asian Studies Review, 38(3), 422-441.

Singh, R., \& Jayraman, V. (2013). Supply chain integration and information technology. International Journal of Economics Business and Management Studies, 2(2), 62-74.

Suryanto, T., Haseeb, M., \& Hartani, N. H. (2018). The correlates of developing green supply chain management practices: Firms level analysis in Malaysia. International Journal of Supply Chain Management, 7(5), 316.

Syadullah, M. (2018). ASEAN banking efficiency review facing financial services liberalization: The Indonesian perspective. Asian Development Policy Review, 6(2), 88-99.

Wong, K. K. K. (2013). Partial least squares structural equation modeling (PLS-SEM) techniques using SmartPLS. Marketing Bulletin, 24(1), 1-32.

Tabachnick, B. G., Fidell, L. S., \& Ullman, J. B. (2007). Using multivariate statistics (Vol. 5). Boston, MA: Pearson.

Tai, W. P., \& Ku, S. (2013). State and Industrial Policy: Comparative Political Economic Analysis of Automotive Industrial Policies in Malaysia and Thailand. JAS (Journal of ASEAN Studies), 1(1), 5282.

Wei, J., \& Liu, Y. (2015). Government support and firm innovation performance: Empirical analysis of 343 innovative enterprises in China. Chinese Management Studies, 9(1), 38-55.

Yuliansyah, Y. (2015). Attributes Influencing Strategic Alignment in the Service Sector: An Indonesian Banking Sector Case Study. International Journal of Business, Economics and Management, 2(2), 34-48.

Zailani, S., Govindan, K., Iranmanesh, M., Shaharudin, M. R., \& Chong, Y. S. (2015). Green innovation adoption in automotive supply chain: the Malaysian case. Journal of Cleaner Production, 108, 11151122.

Zhang, M., Qi, Y., Wang, Z., Zhao, X., \& Pawar, K. S. (2019). Effects of business and political ties on product innovation performance: Evidence from China and India. Technovation, 80, 30-39.

Zhang, S., Wang, Z., Zhao, X., \& Zhang, M. (2017). Effects of institutional support on innovation and performance: roles of dysfunctional competition. Industrial Management \& Data Systems, 117(1), 5067. 


\section{Appendix. Measurement of variables}

\section{Section A}

NAP Strategies

\begin{tabular}{ll}
\hline Q\# & Variables \\
\hline 1 & $\begin{array}{l}\text { Investment Strategy } \\
\text { Issuance of new Manufacturing License for motor vehicles in the category of EEV and exemption of import tax and excise duty for } \\
\text { assembly of Completely Knocked Down (CKD) hybrid and electric vehicles. }\end{array}$ \\
\hline $\begin{array}{l}\text { Technology and Engineering Strategy } \\
\text { Provision of soft loan to develop EV infrastructure such as Plug-In-Hybrid-Vehicle charging station and pre commercialization activities. }\end{array}$ \\
Market Expansion Strategy \\
Establishment of Distribution Infrastructure Network (DIN) and Automotive Parts \& Components For Market Expansion (APCIMEX) to \\
drive export sales. \\
Human Capital Development Strategy \\
Human capital development programmes such as MAJAICO and Malaysia Automotive Institute (MAI) \\
Supply Chain Development Strategy \\
Provision of soft loans to develop new tooling for Tool, Dies and Mould manufacturers. \\
Safety, Security and Environment Strategy \\
Introduction of voluntary vehicle inspection programme (VVIP) to ensure roadworthiness of vehicle and adoption of global 3R (Reduce, \\
Reuse, Recycle) standard as Malaysian Standards in the automotive components.
\end{tabular}

\section{Section B}

Innovation measures

\begin{tabular}{ll}
\hline O\# & Variables \\
1 & (i) Product Innovation \\
2 & Increasing manufacturing quality in automotive components and materials. \\
3 & Decreasing manufacturing cost in components and materials of current products. \\
\hline & Developing newness for current products leading to improved ease of use. \\
\hline & (ii) Process Innovation \\
3 & Determining and eliminating non-value adding activities in production process. \\
4 & Decreasing variable cost per components in the manufacturing process. \\
\hline 1 & Increasing output quality in manufacturing process and techniques. \\
2 & (iii) Marketing Innovation \\
3 & Renewing the design of the current and/or new products through changes in appearance, packaging and shape. \\
4 & Renewing the distribution channels of the current and/or new products. \\
\hline & Renewing the product promotion techniques employed for the promotion of the current and/or new products. \\
2 & Renewing the product pricing techniques for the current and/or new products. \\
3 & (iv) Organizational Innovation \\
& Renewing the routines, procedures and process employed to execute firm activities in innovative manner. \\
\hline
\end{tabular}

\section{Section C}

\section{Performance measures}

\begin{tabular}{ll}
\hline Q\# & Variables \\
\hline 1 & (i) Innovative Performance \\
2 & Ability to introduce new products to market before competitors. \\
3 & Innovations introduced for work processes and methods. \\
4 & Number of innovations under intellectual property protection. \\
\hline 1 & Development of new products follows international standard. \\
2 & (ii) Production Performance \\
3 & Improving in quality of new/existing products (Conformance quality) \\
\hline & Improving in overall production cost \\
\hline & Improving in production volume. \\
\hline 3 & Iii) Market Performance \\
\hline & Improvement in customer satisfaction. \\
\hline & Improving in sales in REM (Replacement Equipment Market). \\
\hline 3 & Improving in sales as OEM manufacturers to Proton \& Perodua. \\
\hline
\end{tabular}

